\title{
建築プロジェクトの組織構造を構築する方法 DESIGNING ORGANIZATIONAL STRUCTURES OF BUILDING CONSTRUCTION PROJECTS
}

\author{
高橋 栄 人* \\ Masato TAKAHASHI
}

\begin{abstract}
The social requirements to building construction projects are to discharge the accountability that should disclose building construction process and discharge participating professionals' responsibilities. In order to satisfy them, this paper tries to propose the designing method of organizational structures for the building construction projects. The following procedure is employed in this study. First, the components of an organizational structure are identified as subsystems that perform allocated functions. Second, the indicators represented relationships among the components are analyzed from the view points of discharging the accountability. Third, the organizational structure is designed by organizing the components under applying the indicators.
\end{abstract}

\footnotetext{
Keywords : Organizational theory, Organizational design, Organizational structure, System, Function, Accountability, Responsibility, Authority, Project management 組織理論，組織編成，組織構造，システム，機能，アカウンタビリティー，責任，権限，プロジェクト。 マネジメント
}

\section{1. 研究の背景・目的}

近年わが国では、建築プロジェクトの実施に際しアカウン タビリティーの充足が求められている。具体的には、建設費 の透明性・公正性の保障等からは建築生産プロセスの開示の 促進が要請され注 1$)$ 、久陷建筑物の社会問題化現象注2)から は関係専門家に帰属する責任（以下帰属責任とする）の明確 化が要請されている。

ここで帰属責任とは、専門家に帰属する固有の責任領域を 呼称するものとする。最も厳格な職能概念を有する専門家注3 は、その専門領域について教育・訓練・経験にもとづいて能力 ある者としての地位を法律によって付与され、依頼者のみなら ず社会に対して中立的で独立した自律的なプロフェショナ ル・サービスを行うことが求められる。このような公共性の 強い専門家の活動からは、他の経済活動から生じる責任とは 異なる固有の責任領域が導かれる注4)。

本稿では、建築プロジェクト組織における主要な構成主体 を各種専門家と仮定して注5)、建築生産プロセスの開示を促 進し関倸専門家の帰属責任を明確にする、建築プロジェクト の組織構造を理論的に構築する方法を提案する。

\section{2. 既往の研究・研究方法・本稿の棲成}

\section{(1) 既往の研究}

既往の研究は、組織構造に関する研究と組織編成方法に関 する研究に区分される。まず、組織構造に関する研究には、 翼 ${ }^{25)}$ 、延藤 ${ }^{26)}$ による住宅産業を対象とした生産機構に関する 一連の研究がある。他方、組織編成方法に関する研究は、さ らに、設計組織と施工組織に関する研究に整理される。前者

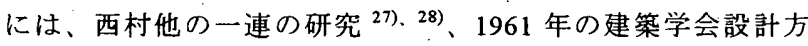
法小委員会、1969 年・1986 年の建築学会大会研究協議会にお ける報告があり、後者には、工事編成に関する多くの研究の 蓄積がある。

本稿と関連の深い組織編成方法に関する研究は、特定のフ ェーズ（設計と施工）を研究対象としている。本稿では、建 築プロジェクトの全てのフェーズにおいて適用可能で、特に 建築プロジェクト運営の初動期（例えば企画フェーズ等）で 検討される、全てのフェーズを対象とした組織編成方法の一 般理論の構築を試みる。

(2) 研究方法・本稿の構成

プロジェクト・マネジメント理論の中の組織マネジメント 論及びその手法を適宜活用し、これらの基礎理論をなす企業

* 京都大学大学院工学研究科建築学専攻 博士後期課程 - 法修 Graduate Student, Dept. of Architecture/Architectural Systems, Kyoto University, LL. M. 
組織を主たる対象とする経営学・経済学にお汁る組織理諭・ 組織編成論の文献に立ち返って検討を試みるものとする。組 織理論等では、建築プロジェクトの適用に有効なシステム ズ・アプローチを活用するシステム論学派注6)を採用し、組織 編成方法を静態的組織編成方法と動態的組織編成方法とに区 分する注 7)。

高橋の前報 ${ }^{23)}$ では、これら企業組織を対象とする組織編成 方法を建築プロジェクト組織へ適用する方法を明らかにし、 動態的組織編成方法について提案した。本稿では前報での提 案をもとに静態的組織編成方法注 8) について検討を進める。 具体的には、動態的組織編成方法において確定された、建築 プロジェクトを完成するために必要な全ての作業内容を作業 単位化したワーク・パッケージ注9)をもとに、組織構造を理論 的に構築する方法を検討する。

組織とは設定された目的を達成するために、各種機能を基 準に区分されたユニットが相互に有機的に結合してシステム 化したユニットの集合体とする。

ここでシステム論学派における一般システム理論を整理 する注 10 )。複雑なシステムは全体として幾つかのサブシステ ムからなり、これらのサブシステムは全体機能に貢献する特 定の部分機能を遂行する。これらの全体システム及びサブシ ステムは、そのメカニズム詳細な記述なしに単にその機能の 記述によって定義される。本稿では、このように機能を基準 に区分された単位であるサブシステムをユニットとする。よ って、一般システム理論から導かれる有力な組織編成方法は、 対象とするシステムを、適切に機能分化する方法を見出し、 半独立の構成要素となる多数の機能的な部分に分解すること である。なぜなら、このようにして導かれた各構成要素は、そ の機能を通じてのみ影響を及ぼしあうため、他の構成要素の編 成過程とは無関倸に編成することができるからである。

現実の建築プロジェクト組織を鑑みれば、建築基準法・建 築士法等の関連法規によって少なくとも設計・施工といった 二大業務（機能）に区分されなければならず、機能を基準と する組織編成が予定されている。

以上より本稿では、建筑プロジェクトの組織構造を理論的 に構筑する方法を、組織マネジメント論・組織理論等の文献 をもとに、次のように検討する。

(1) 機能の選定方法を明らかにすることで、機能を基準に区 分されるユニットを決定する方法を検討する。

(2) 決定されたュニットに、適切なワーク・パッケージを割 り付けることで、ユニットの具体的な履行内容を決定す る方法を検討する。

(3) 組織構造は典型的な組織構造の類型に整理される ${ }^{15)}$ 。そ こで、典型的な組織構造の各類型を決定する方法を検討 する。

(4) 以上までの検討によりユニットが確定されたことで、ユ ニットの有する各種機能を通じてユニット間に相互関倸 が発生している注11)。そこで、組織構造を構築する方法 として、これらユニット間の相互関係を把暒しさらに関 連づけることで各ユニットを組織化する方法を検討する。

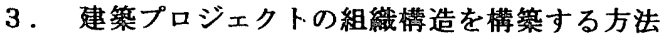

3. 1 ユニットを確定する方法

（1）機能の選定方法

システム論学派によれば、機能とは、設定された目的・成 果物・プロセスを実現するために行うべきことであり、その 内容は、行為（名詞）または行い（動詞）によって表現され る注 12)。そして、これらの機能は、さらに二次的な機能また は派生的な機能に整理される注13)。

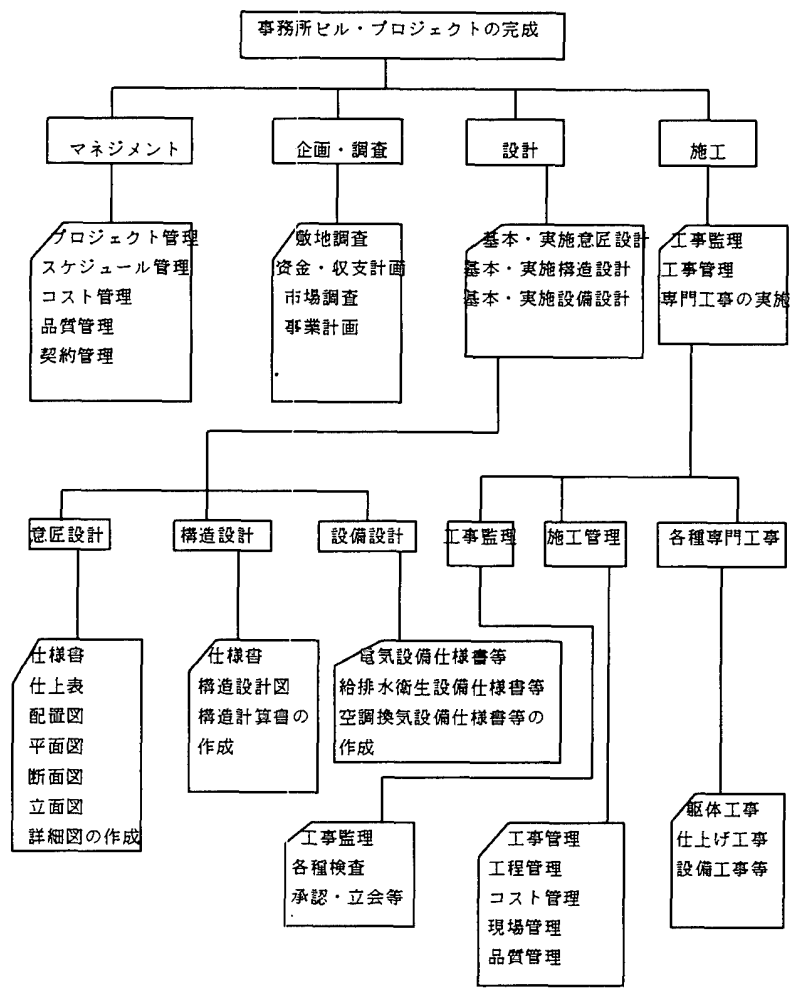

図 1 機能-行為の木

このような機能の選定にあたっては、図 1 機能-行為の木 (Function-means tree) 注 14)を活用する。まず、完成予想建 築プロジェクトを設定する。次の階位には、完成予想建築プ ロジェクトを達成するための基本的な機能と当該基本的な機 能を実現するための衍為を記す。次に、これらの行為を実行 するための二次的な機能が必要かまたは派生的な機能が存す る場合には、当該二次的な機能または派生的な機能とそれら の行為を同様に続けて記す。

以上により、各ユニットを区分する各種機能とその内容を実 現する行為とが明確にされる。この完成した機能-行為の木に ついて機能の部分のみ取り上げて体系化すれば、構築すべき組 織構造のニニットの体系である組織階層化構造（以下 oBS と する：Organizational Breakdown Structure) 注15) が明らかにな る。このようにして導かれた各種機能とその内容を実現する行 為は、組織の外部環境を志向する専門業務と当該組織の内部を 志向寸る特化業務に整理される注 16)。建築プジェクト組織の場 合、これらの機能及び行為は、専門家によって担当されること が法定または技術基淮等で規定され、専門業務となっている場 合が少なくない。 
（2）ユニットヘワーク・パッケージを割当てる方法

上記選定された機能について、担当する専門家を決定し、 適切なワーク・パッケージを割当てることで、ユニットの具体 的な履行内容を決定する方法を検討する。

まず、各種機能を担当する各種専門家の決定にあたっては、 上記各種機能を実現する行為と各種専門家の主要な専門業務 とを比較検討して決定するものとする。ここで専門家の主要 な専門業務は、前記高橋の前報における専門家の固有の職能 モデル等から明らかにする。次に、各ユニットへ適切なワー ク・パッケージを割当てるにあたっては、各種機能を実現する 行為とこれらの行為を担当する専門家の主要な専門業務とを 基準として割当てるものとする。

これらの検討を進めるための分析表が表 1 である。表 1 で は、事務所ビルの新築に際し、マネジメント方式注 17)で $\mathrm{PMr} / \mathrm{CMr}$ が建築主の助言者であり、その他の専門家及び関係 主体を建築主・専門コンサルタント・建築士・建築構造士・ 建築設備士 ・総合工事業者注 18) . 各種専門工事業者注19) と 想定する。また、工事監理は建築計画を担当する建築士によ って一括して行われるものと想定する。建築企画段階におけ る組織編成の検討であり、具体的な分析手順は次のとおりで ある。

(1)縦軸には、建築企画段階で想定し得る、当該建築プロジェ クトの全ての作業内容を作業単位化したワーク・パッケー ジを、フェーズごとにWP0〜WP11 として配置する注20)。 WP0 は、各WPの実施に伴って建築主が行う承認等の各 種行為を取りまとめたものとする。横軸には、上記（1） で選定された各種機能と担当する各種専門家等を配置 する。

(2) 縦軸の各ワーク・パッケージを処理する各種専門家を、 専門家の職能モデル等 (関連法・規則・施行令・各種職 能団体の倫理綱領等）を基淮に、当該専門家の個人的資 質・建築主との信頼関係等を勘酌して決定する注 21)。そし て、決定された各種専門家を法的履行責任の観点から整 理し、各ワーク・パッケージの処理について主たる履行 者となる専門家には PR（主たる責任）を、従たる履行 者または履行補助者となる専門家には LR（限定責任） をそれぞれ表 1 のように記す。これらの検討結果は、各 種専門家ごとに処理すべきワーク・パッケージとその法 的履行責任の内容を明らかにするために、各種専門家に 関する契約内容となる注 22 2)。

(3) 横軸のユニットごとに PR・LR が付されたワーク・パッ ケージが、各ユニットへ割当てられる適切なワーク・パ ッケージであり、ユニットの具体的な履行内容となる。 ここでLR が付されたワーク・パッケージしか存しない ユニットは、当該ワーク・パッケージの処理に関してPR が付されたュニットのサブュニットとして位置づける。 表 1 では、構造ユニットと設備ユニットが設計ユニット のサブニニットとなり、各種専門工事ュニットが施エュ ニットのサブュニットとなる。
表 1 ユニットヘワーク・パッケージを割当てる分析表

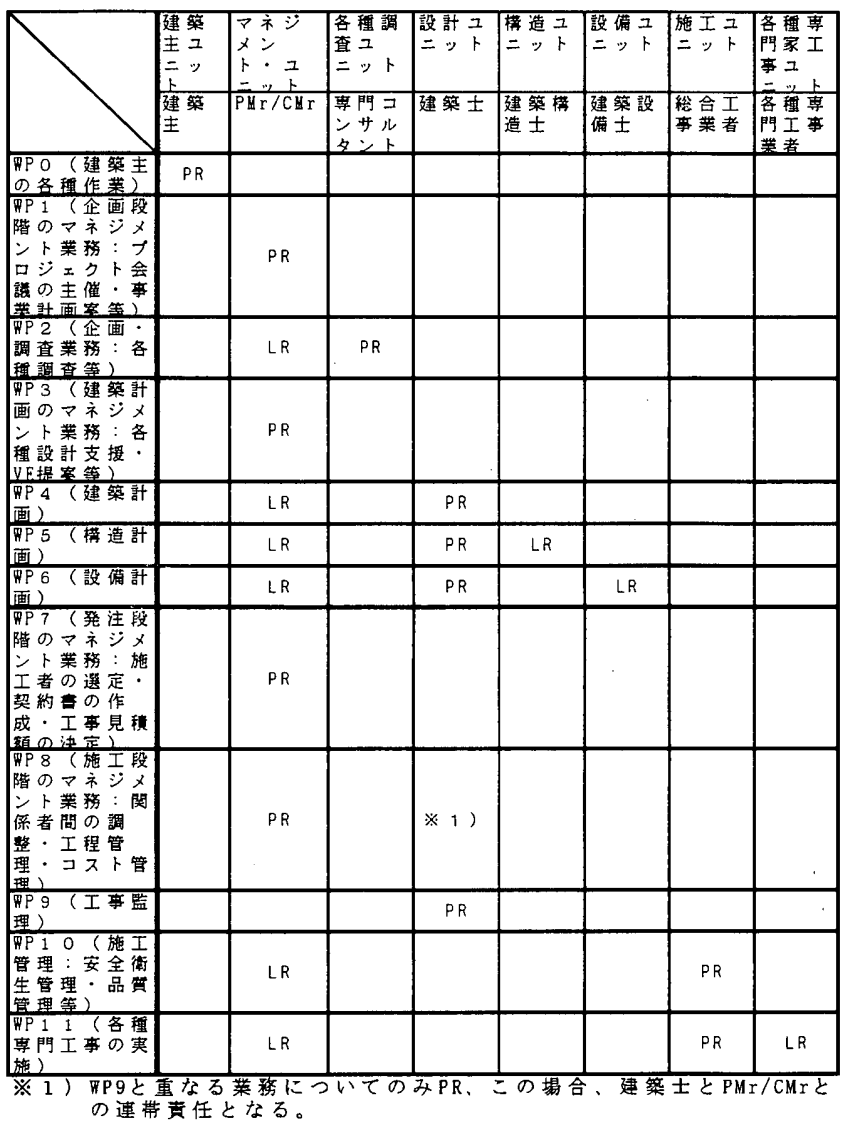

（3）典型的な組織構造の類型を決定する方法

組織理論等によれば、本稿が構築しようとする組織構造は、 規範・貴任・権限等で規定される組織の構成員のための行動 類型及び人間関係の類型を規定する公式組織（Formal organization）である。前記 1 で述べた近年のわが国建筑プロ ジェクトへの要請は、公式組織を明確に記述することである。

公式組織の具体的な表象形態である各種組織構造は、組織 理論等によれば、典型的な組織構造の類型に分けられる。

A 典型的な組織構造の類型

第一に、組織理論等の文献を参考に典型的な組織構造の類型 を整理する。

典型的な組織構造の類型は、まず、(1)ファンクショナル (Functional)組織と (2)プロジェクト組織に大別される。(1)ファ ンクショナル組織とは、機能を基準に区分しかつ必要な権 限・責任を委譲した組織構造である。各種機能の責任者をつ アンクショナル・マネージャー（以下 FMr とする）という。 当該組織の統一的な組織行動に関する権限・責任は、最上位 の階位に位置する統括管理責任者及び各種機能の $\mathrm{FMr}$ が有 する。命令・報告・承認等からなる意志・情報の伝達体系は、 最上位の統括管理責任者から下位の履行者に至る、各種機能 ごとに垂直的な経路となる。他方、(2)プロジェクト組織が現 れる最も一般的な場合は、ある組織構造の特定のユニットを、 時限的な目的達成のためのユニットとした場合の当該ユニッ 卜の組織構造注 23$)$ である。当該組織を統括管理する責任者 (マネジメント機能を担当) をプロジェクト・マネージャー 
(以下 PMr とする) という。当該組織の統一的な組織行動に 関する権限・貴任は、FMr とは独立した PMrに集中する。当 該組織の構成員は、目的達成に必要な各種機能を実現する専 門性をもった構成員からなり、FMr は存在しない。命令・報 告・承認等からなる意志・情報の伝達体系は、PMr と各種専 門性を有する構成員とを直接結んだ PMr を中心とする体系 となる。次に、その他の典型的な組織構造の各頻型は、(1)フ アンクショナル組織の特徵と(2)プロジェクト組織の特徵とを 融合する程度により区分される。よって、典型的な組織構造 の各類型においては、(1)ファンクショナル組織で FMr の権 限・責任が最大となり、(2)プロジェクト組織で PMr の権限・ 責任が最大となる。

以上より、典型的な組織構造の類型を整理すれば、図 2 の ように、上記(1) と(2)の組織構造を対極に、FMr と PMr との権 限・責任の配分状況により(3)ァンクショナル・マトリック ス組織、(4)均衡マトリックス組織、(5)プロジェクト・マトリ ックス組織に整理される。つまり、典型的な組織構造の類型 は、(1)ファンクショナル組織を中心に、PMrの権限・責任（ま たはマネジメント機能)を徐々に強化することで構築される。

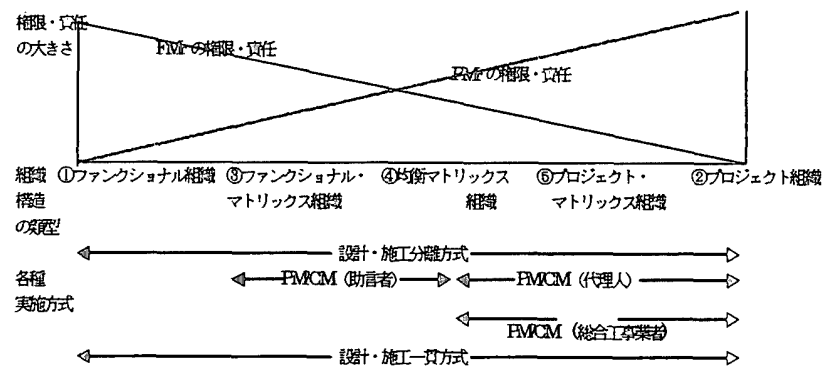

図 2 典型的な組織構造の䫓型の体系

B $\mathrm{PMr} / \mathrm{CMr}$ と $\mathrm{FMr}$ の権限・責任の内容

第二に、 $\mathrm{PMr}$ (以下 $\mathrm{PMr} / \mathrm{CMr}$ とする注 24) ) と FMr の担当 する行為の内容を明らかにし、当該行為に関する権限・責任 の内容を導く。

まず、 $\mathrm{PMr} / \mathrm{CMr}$ の担当する行為について、マネジメント方 式が盛んなアメリカ・コンストラクション・マネジメント協 会 (以下 CMAA とする) の契約約款 5)、6)、アメリカ建築家協 会（以下 AIA とする）の契約約款 ${ }^{1}$ ならびに国土交通省のガ イドライン ${ }^{14)}$ 、日本建築家協会の試案 ${ }^{29)}$ から検討する。する と、 $\mathrm{PMr} / \mathrm{CMr}$ の担当する行為は、 $\mathrm{CMAA}$ の提案する(1)プロジ エクト管理、(2)スケジュール管理、(3)コスト管理、(4)管理情 報システムの構筑、(5)品質管理という区分を基淮に整理され る。次に、FMr の担当する行為について、建築プロジェク・ マネジメント理論に関する女献 4)、17)、19)を参考に検討すれば、 $\mathrm{FMr}$ の担当する行為は、建築プロジェクトを物理的に完成す るためのワーク・パッケージを実行する行為である。具体的に は、(1)PMr/CMrより詳細な実施段階のスケジュール・コスト 管理、(2)建築プロジェクトの完成に必要な資材・人材の調整、(3)各 種技術力の開発・確保、(4)進捗状況の管理等に整理される注25)。

よって、FMrの担当する行為は、建築プロジェクトを物理 的に完成するために必要な専門行為であり、他方、 $\mathrm{PMr} / \mathrm{CMr}$
の担当する行為は、建筑プロジェクトを勃率的に運用するた めの付加的な専門行為である。以上より、FMrの権限・責任 の内容には、建築プロジェクトを物理的に完成するために必 要不可欠な各種資材等䖯調達・管理・加工・処分するといっ た各種財産管理に関す引権限及び撌任 (以下財産管理権注 26) とする）が、建築主から委譲されていることを必要とする。 他方、 $\mathrm{PMr} / \mathrm{CMr}$ の権限・責任の場合、その担当する行為が建 築プロジェクトを効率的に運用するための付加的な業務であ るため、必ずしも財産管理権が委譲されることを必要としない。

C 典型的な組織構造の,類型を決定する方法

第三に、このような $\mathrm{FMr}$ と $\mathrm{PMr} / \mathrm{CMr}$ とに関する権限・責 任の相違に着目し、典型的な組織構造の各類型における上記 $\mathrm{FMr}$ と $\mathrm{PMr} / \mathrm{CMr}$ の権限・責任の配分状況を検討する。

典型的な組織構造の頻型は、(1)ファンクショナル組織と(2) プロジェクト組織を対極に図 2 のように整理される。(3)ファ ンクショナル・マトリックス組織は、(1)ファンクショナル組 織をもとに、各ュニットを調整・監督するために、プロジェ クト管理・スケジュール管理等を行う $\mathrm{PMr} / \mathrm{CMr}$ を導入した類 型である。FMr は完全な財産管理権を有する。(4)均衡マトリ ックス組織は、上記(3)の類型における $\mathrm{FMr}$ の財産管理権を $\mathrm{PMr} / \mathrm{CMr}$ と共有または均等になるまで移転した、(1)と(2)の中 間に位置する穎型である。 $\mathrm{FMr}$ と $\mathrm{PMr} / \mathrm{CMr}$ との権限・責任を 均衡させることで、 $\mathrm{FMr}$ と $\mathrm{PMr} / \mathrm{CMr}$ との協働的組織運営が意 図されている。(5)プロジェクト・マトリックス組織と(2)プロ ジェクト組織は、過半以上の財産管理権を $\mathrm{PMr} / \mathrm{CMr}$ に移転し てその権限・責任を強化する一方、FMrの権限・責任を技術 的事項に関する助言者へ弱めた類型で(2)に偏向する注 27)。財 産管理権が完全に $\mathrm{PMr} / \mathrm{CMr}$ に移転した穎型が(2)プロジェク 卜組織であり、その一部を FMrのもとに留めた類型が(5)プロ ジェクト・マトリックス組織である。よって、典型的な組織 構造の各類型は、FMr 上 $\mathrm{PMr} / \mathrm{CMr}$ との財産管理権の配分状況 に依存する。つまり、典型的な組織構造の各類型は、 $\mathrm{PMr} / \mathrm{CMr}$ が担当するマネジメント機能を有するユニットに委譲される 財産管理権の程度によって決定される。

典型的な組織構造の各類型が採用し得る各種実施方式注 287 を示せば、図2下段のとおりである注29)。なお、図2 下段の 矢印は、各種実施方式を適用し得る典型的な組織構造の各類 型の艘囲を示したものである。

以上より、対象とする建築プロジェクトの諸条件・関係専 門家の個人的資質・建築主との信頼関倸等を基準に、構築す べき組織構造をいかなる典型的な組織構造の類型とし、いか なる実施方式を採用すべきかを勘配して、マネジメント機能 を有するユニットに配分する財産管理権の程度を決定しなけ ればならない。そしてこの決定内容は、関係専門家に関する 重要な契約内容となる。

\section{2 ユニットを組䌉化する方法}

（1）各ユニットの相互関俰を把握する指摽の選定

以上までの検討により、各種機能を有するユニットが確定 されたことで、ニニット間に相互関係が形成される。これら 
の相互関倸の内容を把握するために、当該相互関倸を把握す る指標を検討する。このような検討について組織理論等では 伝統的に、(1)権限注30)、(2)責任注31)、(3)意志決定・報告 · 承認等のコミュニケーション注32)等を揭げる。そこで、ュ ニット間の相互関倸を把握するためにいかなる指標を選定す べきかといった選定基準が問題となる。

そもそも本稿の目的とするところは、建筑生産プロセスの 開示を促進し関係専門家の帰属責任を明確にする、建築プロ ジェクトの組織構造を理論的に構筑する方法を検討すること である。よって、このような目的に有用な選定基準としての指 標を、責任・権限・監査とし、その内容を次のように定める。

責任とは、特定の事項・役務を履行する法的義務である。

権限とは、他者の行為へ命令・変更・禁止といった効果 を及ぼすことを意図した行為をする権限である。このよ うな権限には、法的なものと、専門性・経験・知識・情 報の片務性・人望といった何らかの優位性にもとづくも のとがある。

監查とは、他者の履行結果に対して、各種業績評価規準 との適合性を審査・検査し、報告する義務である。

これら三者を指標として設定した理由は次のとおりである。

第一に、責任・権限は、各ユニットの有する機能の実現を管 理・操作・モニターするために不可欠な指標であるかららである。

各ユニットが有する機能は、当該ユニットを担当する各種 専門家によって履行される。そこでまず、専門家による確実 な履行を委託者である建築主側から検討すれば、当該履行内 容を、強制力を有する法的な責任として規定することが必要 である。この具体的な検討が、前記 3 ， 1 表 1 における、各 ワーク・パッケージを処理する専門家の決定と、当該処理に関 する責任の内容（PR:主たる責任、LR:限定責任）の検討であ る。つまり、各ユニットを担当する専門家が履行主体となり、 各ワーク・パッケージが履行範囲を明らかにし、PR・LR がそ の責任の内容を定める注 3 3)。他方、専門家による確実な履行 を受託者である専門家側から検討すれば、専門業務を円滑に 実施するために、関連情報・資材 ・凟金等を自己の名の下に 集中し、必要に応じて履行補助者一指示・命令する等、当該 専門業務を履行するための裁量権(権限)が必要となる。よっ て各ユニットの有する機能の実現を管理・操作・モニターす るためには、主として、委託者側からは責任が、受託者側か らは権限が必要となる。しかし、これらの権限・貴任は、そ もそも担当する行為の履行という同一の事象を、権利または 義務といった異なる側面から捉えたものであり、重複する場 合が少なくない注34)。そこで本稿では、責任の指標の適用範囲 を、前記ユニットへワーク・パッケージを割当てる方法の中の 履行主体・履行範围・責任の内容 $(\mathrm{PR} \cdot \mathrm{LR})$ の検討及び専門 家が担当する行為に関する報告義務とし、その他の事項は権 限に関する事項と整理する。

第二に、監查を指標として取り上げた意義は、監査が、各 ワーク・パッケージの処理結果に対する各種規準の適合性の 判定行為及び判定者を明確にするため、上記本稿の目的の実 現に有用であるからである。

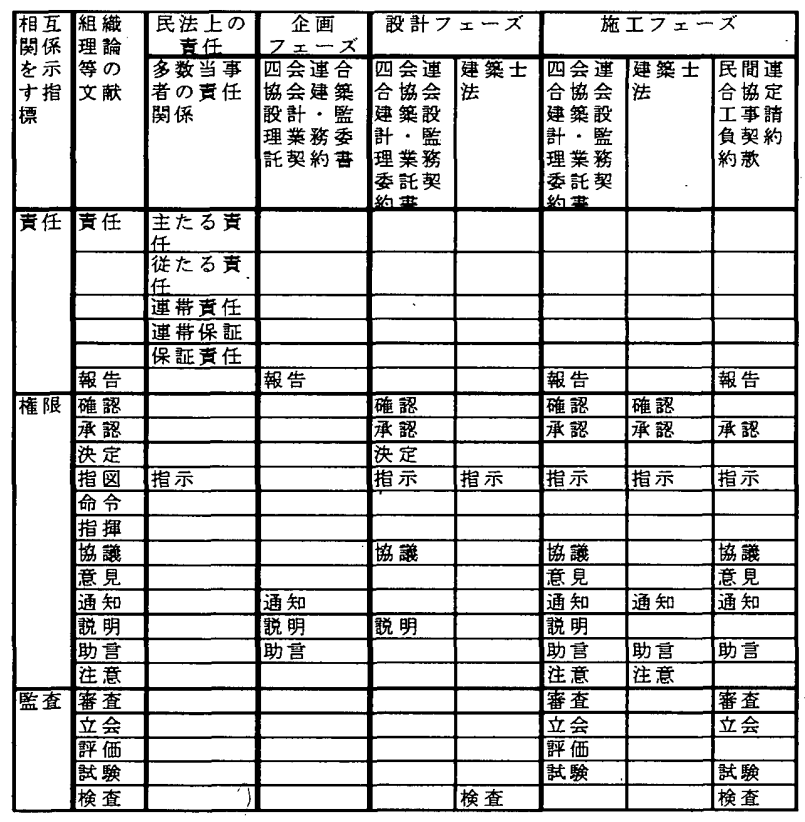

これらの指標が具体的にどのような行為として現れるか を検討したものが表 2 である。表 2 は、組織理論等の文献・ 民法典・建築士法・各種契約約款から、建筑プロジェクト組 織における相互関係を示す行為をフェーズごとに抽出し、上 記責任・権限・監查を基隻に整理したものである。そして、 上記文献を参考に、同様の役割を有するものを取りまとめて、 三者の指標を基準に相互関係を示す指標として整理したもの が表 3 である。

\section{表 3 相互関係を示寸指標}

\begin{tabular}{|c|c|c|c|c|}
\hline 供任 & \multicolumn{2}{|c|}{ 権限 } & \multicolumn{2}{|c|}{ 監查 } \\
\hline 指標 記号 & 指 標 & 記号 & 指懐 & 記昜 \\
\hline 主たる定任.PR & 承㒛 & $A p$ & 検查 & 11 \\
\hline 限定年任 & 指示 & 0 & 番查 & IE \\
\hline 㘧笘 & 協撞 & $\mathrm{Ne}$ & 章会 & At \\
\hline & 通 & No & & 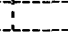 \\
\hline i & 助言 & Ad & & \\
\hline
\end{tabular}

表 3 において、まず、責任の限定責任は、表 2 の従たる責 任・連帯責務・連帯保証・保証責任を取りまとめたものであ る。次に、権限について、承認は同表の確認・決定を、指示 は同表の指図・命令・指揮を、助言は同表の意見・注意を、 通知は同表の説明をそれぞれ取りまとめたものである。最後 に、監查について、検查は同表の試験を、審査は同表の評価 をそれぞれ取りまとめたものである。

表 3 の権限を基準とする相互関係を示す指標は、法的な権 限にもとづく指標を承認・指示とし、何らかの優位性にもと づく指標を協議・通知・助言とする。

（2）ユニットを組織化する方法

組織構造を構築する方法の検討として、ユニット間の相互 関係を把握しかつ関連付けてニニットを組織化する方法を明 らかにする。具体的には、各ユニットに割当てられたワーク・ パッケージ間に扔ける相互関係を、表 3 における相互関倸を 示す指標を適用して明らかにする方法を検討する。 
表 4 は、各ユニットに割当てられたワーク・パッケージ間 の相互関倸を把握しかっ関連付ける分析表である。検討手順 は次のとおりである。

(1) 綎軸・横軸には、各ニニットの各ワーク・パッケージを フェーズごとに並ベる（表４における各ワーク・パック ージの内容は前記 3 ． 1 表 1 の設例によるものである)。 この場合、表 1 の検討結果より、サブュニットとなる構 造ユニット・設備ユニット・各種専門工事ュニットは、 その関保を明示するものとする。

(2) 全てのワーク・パッケージ間の相互関係を、横軸の各ワ ーク・パッケージを能動主体とし、縦軸の各ワーク・パッ ケージを受動主体として、能動主体から受動主体への能
動関係を、表 3 相互関係を示す指標で記す。但し、同一 主体のワーク・パッケージ間を検討してしまう場合には 斜線を引き、なんら相互関倸を有しないワーク・パッケ ージ間には「Фなし」と記すものとする。ここで能動関 倸とは、例えば、分る一対のワーク・パッケージ、ワー ク・パッケージn (以下 WPn とする) とワーク・パッケー ジn+1（以下 WPn+1 とする）との次のような相互関倸 である。

(1) WPn 能働主体とした場合の WPn（能動主体）から WPn+1（受働主体）への関係

(1) WPn+1 を能動主体とした場合の WPn+1（能働主体） からWPn（受働主体）への関係

表 4 ユニットを組織化する分析表

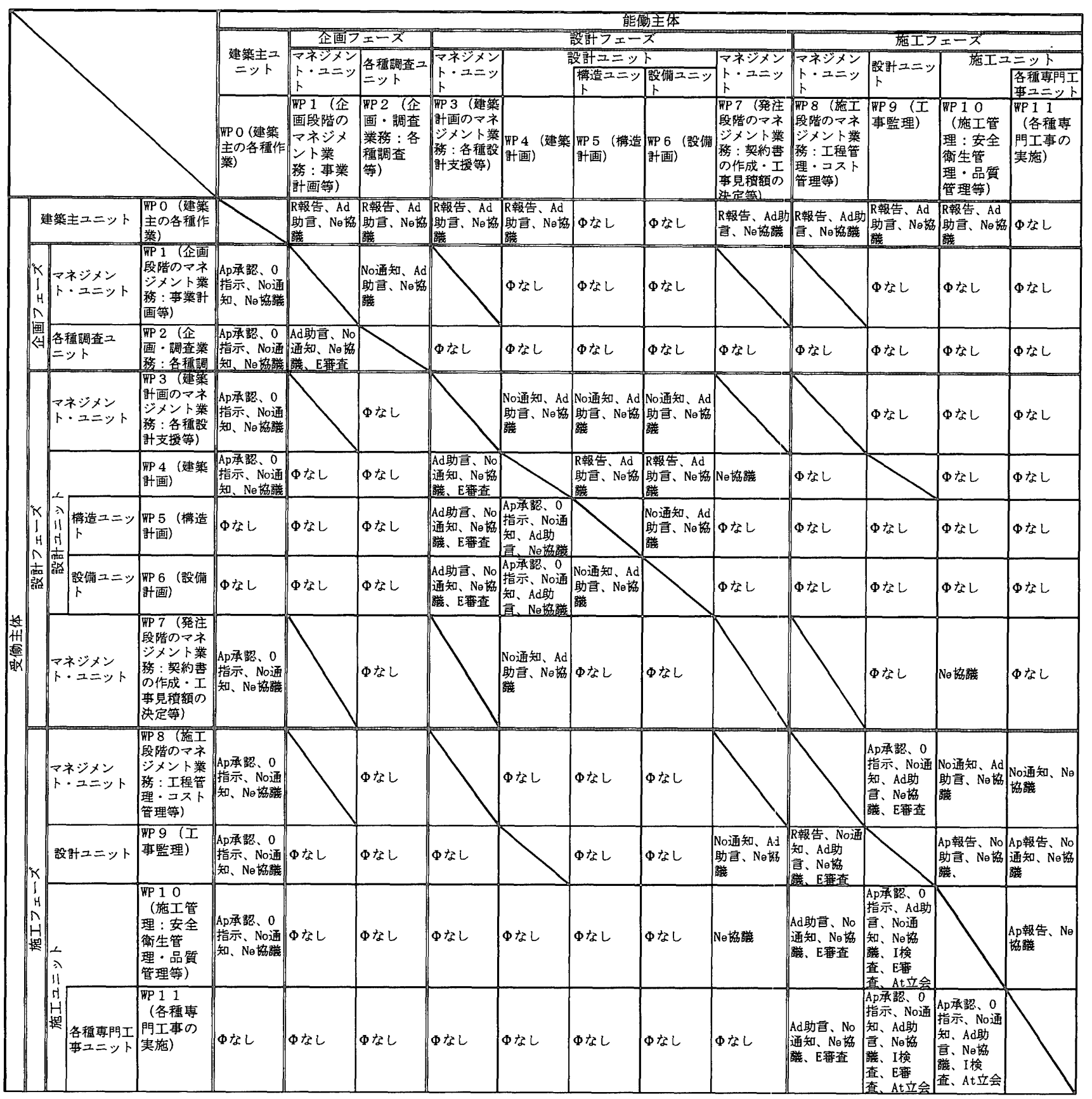


以上の検討より、表 3 の各指標の観点からユニットの組織 化が行われ、組織構造が構築されたことになる。

次に、当該組織構造を明示的に示す図 3 のようなフロー・ モデルを記述する方法を検討する。

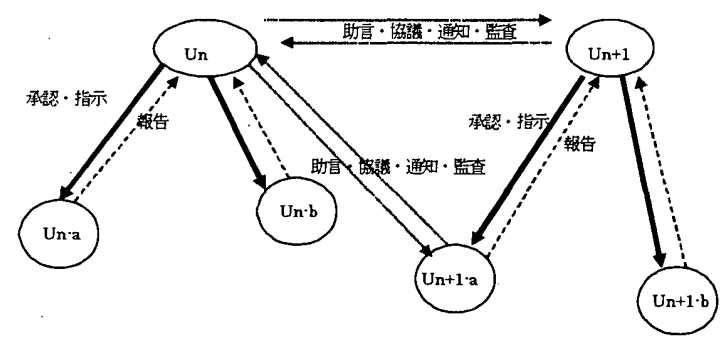

図 3 組織構造を示すフロー・モデル

図 3 において、ユニットn.(Un) とュニットn+1 (Un+1) は、OBSにおけるある異なる基本的な機能を有するユニット とする。そしてこれらのユニットは、さらに二次的な機能に 階層化されて、Unは Un-a、Un-bに、Un+1 はUn+1-a、Un+1-b に階層化されるものとする。まず、同じ基本的な機能の体系 にあるユニット間の相互関係を記述する方法を検討する。Un 系列 $(U n+1$ 系列) の場合、Un-a、Un-b (Un+1-a、Un+1-b) から上位の階位にある Un $(U n+1)$ への能動関倸は、図 3 で はそれぞれの機能を処理した結果（履行内容）の報告を記し た(前記 3.2 表 3 の責任に関する指摽は破線で示す)。逆に、

Un (Un+1) 加 Un-a、Un-b (Un+1-a、Un+1-b) への能働関 倸は、当硋報告に対する承認、履行内容に関する指示を記し た（表 3 の権限に関する指標は実線（太）で示す)。次に、異 なる基本的な機能の体系（Un 系列と Un+1 系列）にあるユニ ット間の相互関係を記述する方法を検討する。この関係にお いて各ユニットは、前記 2 . (2)で述べたとおり、各種機能 を通じて影響を及ぼすのみで、各種機能を遂行するメカニズ ムの詳細とは関係しない。よって、異なる機能を有するユニ ット間の関係は、原則的に、表 3 の権限の中の協議・通知 • 助言、監查の各指標によってのみ示されることになる（図 3 では実線（細）で示した）。これは、表 3 の責任、権限の中の 承認・指示といった法的効果を伴う指標は、各種機能の遂行 （履行）を示寸指標となるからである。但し、マネジメント 機能を有するユニットが財産管理権を委譲された場合には、 当該ユニットと異なる機能を有するユニットとの関倸は、法 的効果を伴う指標によっても示されることになる。

\section{4.まとめ}

近年のわが国建築プロジェクトへの社会的要請は、建築生 産プロセスの開示を促進し関係専門家の帰属責任を明確にす ることであった。そこで本稿では、建築生産プロセスの開示 を促進し関倸専門家の帰属責任を明確にする、建築プロジェ クトの組織構造を理論的に構築する方法を次のように提案した。

(1) ユニットを確定する方法

建築プロジェクトの組織構造は、機能を基準に区分された ユニットからなることを明らかにした。そこで、機能の選定
方法を示し、次に、選定された機能について、担当する専門 家を決定し、適切なワーク・パッケージを割当てる方法を明ら かにすることでュニットを確定する方法を提案した。そして、 このユニットを確定する方法が、各種専門家に関する契約内 容をも明らかにすることを示した。さらに、典型的な組織構 造の各類型は、マネジメント機能を有するユニットへ委譲さ れる財産管理権の配分状況によって特徴づけられることを明 らかにし、典型的な組織構造の各類型の決定方法を明らかに した。

$$
\begin{aligned}
& \text { (2) ユニットを組織化する方法 } \\
& \text { ユニットが確定されたことで、ユニット間に相互関係が発 }
\end{aligned}
$$
生する。そこで、建築生産プロセスの開示を促進し関係専門 家の帰属責任を明確にするユニット間の相互関保を把握する 指標を分析し選定した。次に、当該指標を用いて各ユニット を組織化する方法を、建築プロジェクトの組織構造を構筑す る方法として提案した。最後に、導かれた組織構造を明示的 に示すフロー・モデルを記述する方法を提案した。

本稿の提案より、建築プロジェクトへの各種（社会的）要 請を基淮として、ニニット間の相互関係を把握する指標を選 定することで、変遷する各種（社会的）要請に適合する建築 プロジェクトの組織構造の構筑が可能となると考察される。 本稿で残された課題は、本稿の提案する建築プロジェクトの 組織構造を構築する方法を、現実の建築プロジェクトに適用 しその妥当性を検証することである。

注

注1）建設省編 $(2000)^{100}$ ，94 頁。公共事業では建設費の透明性・公正性 の保障、民間事業では建築主からのコスト・コントロール、モニタ リングの確保等が要請されている。

注2） 久陮住宅への対策として「住宅の品質確保の促進等に関する法律うが 平成 12 年 4 月 1 日に施行された。

注3）専門家は職能概念を有寸る専門家と、職能概念を有しない専門家に 区分される。詳細は高橋 $(2002)^{23)} 、 239$ 頁。

注4)このように最も厳格な職能概念を有する専門家の帰属責任を明らか にすることで、職能概念を有しない専門家についてもその帰属責任 が相対的に明らかとなる。詳細は高橋 (2002) ${ }^{23)} 、 239-240,243$ 頁。

注5)このような仮定は、建築プロジェクトにおける各種作業の権限・責 任が、最終的に各種専門家に帰属することから、建築生産プロセス の開示を促進し関釈専門家の帰属責任を明確にする組織編成力法の 検討には有用である。建築プロジェクトの完成に必要な各種作業は 専門的な作業であり、専門領域ごとに各種専門家が担当する。仮に、 補助者と共に作業を実施する場合、当該補助者は担当専門家の指 図・監督に從う履行補助者と整理され、各種作業に関する権限・貴 任は最終的に担当専門家に帰属する。よって、建築プロジェクト組 織の主要な構成主体を各種専門家とすることは、専門家の帰属責任 の検討のみならず、組織構造の主要な構成主体の権限・責任の配分 方法を検討する、建築生産プロセスの開示を促進する組織編成方法 の検討においても意義を有する。

注6) 組織理論等はその形成史から、古典的管理論学派・人間関係論学派・ システム論学派に整理される。これら学派の建筑プロジェクト組織 への適用を検討寸饥ば、古典的管理論学派は複雑な事象の検討には 不向きであり、人間関俰論学派は極めてミクロ的な分析手法である。 そこで本稿ではシステム論学派を採用する。

洼7) Jones (1995) ",pp47-123,417-528. 詳しくは高橋 (2002) ${ }^{29} 、 240-241$ 頁を参照

注8) 高橋 $(2002)^{23} 、 240$ 頁。

注9）ワーク・パッケージは、組織編成上の基本操作単位でもある。ワーク・ パッケージの概念については、高橋 (2002) ${ }^{23} 、 241$ 頁を参照また、 ワーク・パックージの大きさを確定する方法についは、高橋 (2002) ${ }^{23)}$ 、 242-243 頁を参照

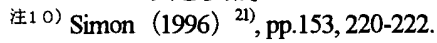


注11) システムの本質は構成要素間の相互関倸にある。

注1 2) Dym and Litter (1999) §),pp.110. さらに機能は、Y=f(Xn)において、 特定の各種投入物 $\mathrm{Xn}$ をもとに意図された達成寸べき目的 $\mathrm{Y}$ を案胃 寸るための関数 $\mathrm{f}(\mathrm{Xn})$ として説明し得る。

注1 3) Dym and Litter (1999) ${ }^{8)}$, pp.110-111.

注1 4) Dym and Litter (1999) 8), pp.116.

注15)高橋 (2002) ${ }^{23)} 、 241$ 頁。

注1 6) Luhmann (1976) ${ }^{16}$, pp.56.

注17) プロジェクト・マネジメント方式とコンストラクション・マネジメ ント方式の差異は、業務範囲の広狭によるもので本質的な相違では ないるそこで本稿では、両方式を総称してマネジメント方式とする。

注18）施工ユニットを担当する総合工事業者の主体は、当該施工ユニットの 全ての権限・責任を有する現場代理人、施工ユニットの中心的業務で ある施工技術の管理を担当する監理技術者または主任技術者等である。 ここて監理技術者等は、建築施工管理技士または同等の能力を有寸る 々認められる専門家である。また現場代理人は、特に定めはないが監 理技術者との兼任が許されるなど、監理技術者等を経験した熟練した 専門家である場合が多い。よって、建築プロジェクト組織における主 要な構成主体を専門家とする本稿仮定は、当該ユニットにおいても 意義を有する。しかしここでは、建築企画段階における組織編成であ るため、施工ユニットの主体を総合工事業者と総称寸る。

注19）専門工事業者は専門家でない場合が少なくない (専門家か硚かの判 定方法については高橋 (2002) ${ }^{23)} 、 239-240$ 頁を参照)。建築プロジ エクトにおいて専門工事業者は、総合工事業者と下請負契約を締結 する場合が一般的であり、建勧主とは直接的な契約関係にない。す ると、専門工事業者は専門家である総合工事業者の管理・監督に従 う関係に位置付けられ、建築主との関係では、最終的な権限・責任 は専門家である総合工事業者が有することになる。よって、建築プ ロジェクト組織における主要な構成主体を専門家とする本稿の仮定 は、当該ユニットを含めた関係においても意義を有する。

注20) WP1〜WP11 は、設例の諸元をもとに、建筑プロジェクトの完成に 必要な全作業内容を作業単位 (タスク).に分割寸るWBS の分析 (詳 しくは高橋 $(2002)^{23)} 、 241$ 頁を参照)によって導かれたタスクであ るので、WBS の分析の定義により、原則的に、網羅性・独立性が保 障される。しかし、PMr/CMr の施工段階のマネジメント業務 (WP8) と建勧士の工事監理業務（WP9）とは業務が重畳寸る場合が少なく なく、この場合、独立性が保障されない。これは、欧米のマネジメ ント方式をわが国に遒入したため、現段階ではマネジメント業務に 関する明確な基淮が未だ示されていないためである。そこでこの取 り扱いについて表1で注記した。

注21) 本稿が想定する建築プロジェクトの組織編成は、建築企画等といっ た建築プロジェクトの比較的初期のフェーズで検討される場合が多 い(日本電信電話株式会社 建築部編 $(1987)^{30}$ ) 37 -39 頁)。よって、 各種専門家が処理する履行内容を検討することは、各種専門家に関 する契約内容を検討することになる。

注22) 専門家ごとに PR・LR が付されたワーク・パッケージの作業内容が 専門家に関する契約の履行内容となる。担当するワーク・パッケージ にPR が付されている場合、担当専門家は、当該ワーク・パッケージ の履行に関し完全な契約上の責任を有することになる。同様に LR が付されている場合、担当専門家は、当該ワーク・パッケージについ て PR が付された専門家 (主たる履行責任者)の従たる履行責任者ま たは履行補助者と位置づけられ、当該ワーク・パッケージの履行に関 し制限された契約上の責任を有することになる。

注23) 前記 2.（2）よりユニットは、対象とする組織のサブシステムと なるので組織構造が記述される。

注24) 上記 3.1 (3) A では主として企業組織を検討対象としたが、以 下では建築プロジェクト組織を検討対象とする。建築プロジェクト 組織ではマネジメント機能はPMr か CMrによって担当される。よっ て以下では $\mathrm{PMr} / \mathrm{CMr}$ とする。

注25) Cleland (1983) ${ }^{4)}, \mathrm{pp} .353$.

注26) 建筑プロジェクトを完成するためには、究極的に建筑主に帰属する 各種財貨を処分・変更し得る権限が必要となる。建築主に帰属寸る 各種財貨に関する当該権限を財産管理権とする。

注2 7) Larson (1985) ${ }^{19}$, pp.40-44.

注28）実施方式に関する研究の成果である The American Institute of Architects California Council (1996） ${ }^{2)}$ の文献を参考に、わが国人導入 可能な実施方式として設計・施工一貫方式、設計・施工分離方式、 マネジメント方式 (PMr/CMr が助言者の場合)、マネジメント方式
(PMr/CMr が代理人の場合)、マネジメント方式（PMr/CMr が総合 工事業者の場合）を採用し得る実施方式の類型とした。

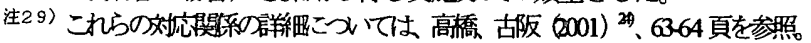
注30) King (1990) ${ }^{13)}$, pp.330.

注31) Simon (1996) ${ }^{21)}$,pp.16,91. Braun (1987) ${ }^{3)}$,pp.242.

注3 2) Luhmann (1976) ${ }^{16}$, pp.67-91, Dalton (1970) ${ }^{7}$, pp.1.

注33) 前記 3. 1 ．（3）〔゙検討したように、マネジメント機能に関する 各ワーク・パッケージにかかわる質任には、さらに財産管理権（権限 と義務の総称概念と定義した）が付加される場合がある。

i注34) Siman (1950) ${ }^{27}$,pp215. Schmalentach (1959) ${ }^{20}$,pp44.Luhman (1976) ${ }^{10}, \mathrm{pp} 41$.

\section{参考站献}

1) The American Instiute of Ardriteds, ALA DocumentB801/CMa, AIAPress, 1992

2) The American Instutute: of Architects Califomia Council, Handbook on PROJECT DELIVERY, AIA Califomia Council, 1996.

3) Braun B, Organization Inctustry, 1987.

4) Cleland, David, System Analysis and Project Management, MoGraw Hill, 1983.

5) The Construction Management Association of America (CMAA) ,CMAA Document No.GMP-1 (1999), CMAA Document No-A-1(1999) CMAA.

๑) The Construction Management Association of America (CMAA), Standard Construction Management Services and Practice, CMAA, 1999

7) Dalton Gene W. and Lawrence Paul R, Organizational Structure and Design, Richard D. Irwin, 1970.

8) Dym, Clive L. and Liter, Patrick, Engineering Design, Wiley, 1999.

9) Fincham, Robinand Rhodles, Pter, Principles of Organizational Behavior, Oxford, 1999.

10)建設省編『建設白劃2000』ぎょうせい・2000 年。

11) Hodge, Billy J. and Anthony, William P., Organizational Theory, Allyn and Bacon, 1991.

12) Jones, Gareth R, Organizational Theory, Addison Wesley Pub.1995.

13) King D., Full Cycle of Organizational Inctustry, 1990.

14）国土交通省「CM 打式活用ガイドラインー日本型 $\mathrm{CM}$ 方式導入に向 けて一」2002 年。

15) Larson, Erik W. and Grobeli, David H., "Project Management Structure," Project management journal, June 1985.

10) Luhmann Niklas V., Fiunktinen und Folgen Formaler Organisation, Ducker and Humbolot, 1976. 浴 豊、長谷川幸一訳『公式組織の機能とその派 生的問題 (上巻)』新泉社・1992 年、同訳『公式組織の機能とその 派生的問題 (下巻)』新泉社・1996 年)

17) Reschke, Hasso and Sichelle, Heiz, Dimensions of Project Management, Springer-Verlag, 1990 .

18) Robbins, Stephan P., Organization Theory, Prentice-Hall, 1990

19) PMI Standards committee, $A$ Guide to the Project Management Body of Knowledge, PMI press, 1996

20) Schmalenbach Eugen, Uber Dienststellengliedenung im Grossbetribe, Westdeutscher Verlag, 1959.

21) Simon, Herbert A, The Science of the Artificial, MTT Press.1996. (稻葉元 吉、吉原英樹訳『シススラムの科学』パーソナルメディア・1999 年)

22) Simon, Herbert A, Simithburg, Donald W. and Thompson, Victor A, Public Administration, Transaction Publischers, 1950

23）高橋栄人「専門家の職能概念を活用した建築プロセスの開示と関係 専門家の帰属責任旅明確にする建築プロジェクトの組織編成方法 に関する研究一建築プロセスを組織構造に反映させる動態的組織 編成方法の理論的構筑一」日本建築学会計画系論文集 第 551 号, 237-244 頁, 2002 年 1 月。

24）高橋栄人、古阪秀三「建筑プロジェクトにおける組織編成方法に関 する検討」 日本建筇学会 建筑経済委員会第 17 回建築生産シンポジ ウム論文集 57-64 頁, 2001 年7月。

25）巽 和夫、延藤安弘他「建売住宅建設業者の構成と生産機構」日本 建筑学会近畿支部研究報告集 157-160 頁, 1968 年 5 月。

26) 延藤安弘、翼 和夫「住宅産業形成上の問題点」日本建築学会近畿 支部研究報告集 205-208 頁, 1971 年 5 月。

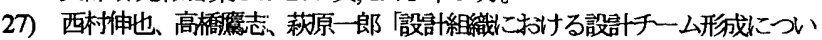
て」日本建築学会計画系䜽文報告集 第397号,6069 頁, 1989年3月。

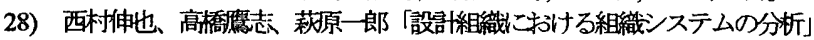
日本建築学会計画棌論文報告集 第405号,67-75 頁, 1989年11月。

29）日本建筑家協会編「IIA-CM ガイドライン」日本建築家協会·1998年3月。

30）日本電信電話侏式会社 建築部編「インテリジメントビル設計計画 ガイドブック」通信建築研究所・1987年。 